\title{
ANALISIS KINERJA PENILIK PNF DI KABUPATEN GORONTALO
}

\author{
Abdul Rahmat*
}

\begin{abstract}
The role of inspectors is considered as highly strategic to helping the implementation of nonformal education in Indonesia. This research has aim to describe the inspectors' performance in the implementation and quality control of nonformal education. With fenomologis approach, the data is collected by observation, interview, and document study. The result of this research showed that the inspector in Gorontalo not implement the entire main task and the function optimally yet. Because of that, this research suggested to increasing the competency of inspector by upgrading and another relevant forum.
\end{abstract}

Keywords: performance, inspector, quality, and professionalism

\begin{abstract}
Abstrak
Kedudukan penilik dipandang sangat strategis dalam membantu penyelenggaraan pendidikan nonformal di Indonesia. Penelitian ini bertujuan untuk mendeskripsikan kinerja penilik dalam penyelenggaraan dan pengendalian mutu pendidikan nonformal. Dengan menggunakan pendekatan fenomonologis, data dikumpulkan melalui observasi, wawancara, dan studi dokumen. Hasil penelitian ini menunjukkan bahwa penilik di Kabupaten Gorontalo belum melaksanakan semua tugas pokok dan fungsinya secara optimal. Oleh karena itu, penelitian ini menyarankan meningkatkan kompetensi penilik melalui penataran dan forum lain yang relevan
\end{abstract}

Kata-kata Kunci: kinerja, penilik, mutu, dan profesional

\section{PENDAHULUAN}

\section{Latar Belakang}

Hasil kerja yang dicapai oleh seseorang atau sekelompok orang dalam suatu organisasi sangatlah penting, sesuai dengan wewenang dan tanggung jawab masing-masing, dalam rangka upaya mencapai tujuan organisasi bersangkutan secara legal, tidak melanggar hukum dan sesuai dengan moral maupun etika, atau yang lebih dikenal dengan istilah kinerja. Istilah kinerja atau prestasi kerja berasal dari kata job performance yaitu prestasi kerja yang dicapai seseorang dalam melaksanakan tugas pokok, fungsi dan tanggung jawab yang diberikan kepadanya. Kinerja sangat penting bagi setiap organisasi. Oleh karena itu, untuk mencapai sasaran-sasaran strategis, diperlukan kemampuan untuk mengelola kinerja para pekerjanya secara tepat (Sinaulan, 2007:35). Dalam pengelolaan tersebut, harus selalu konsisten dengan kebutuhan-kebutuhan organisasi, agar dapat mewujudkan keberhasilan jangka panjang. "An organization's long-term success in meeting its strategic objectives rests with its ability to manage employee performance and ensure that

* Dosen Jurusan Pendidikan Luar Sekolah Universitas Negeri Gorontalo performance measures are consistent with the organization's needs" (Mello, 2002:298).

Kinerja diartikan juga sebagai tingkat atau derajat pelaksanaan tugas seseorang atas dasar kompetensi yang dimilikinya. Istilah kinerja tidak dapat dipisahkan dengan bekerja karena kinerja merupakan hasil dari proses bekerja. Dalam konteks tersebut, maka kinerja adalah hasil kerja dalam mencapai suatu tujuan atau persyaratan pekerjaan yang telah ditetapkan. Kinerja dapat dimaknai sebagai ekspresi potensi seseorang berupa perilaku atau cara seseorang dalam melaksanakan tugas, sehingga menghasilkan suatu produk (hasil kerja) yang merupakan wujud dari semua tugas serta tanggung jawab pekerjaan yang diberikan kepadanya (Siahaan, 2006:23).

Menurut Hadari (2001: 234-243), penilaian kinerja dilakukan sebagai proses mengungkapkan kegiatan manusia dalam bekerja, yang sifat dan bobotnya ditekankan pada perilaku manusia sebagai perwujudan dimensi kemanusiaan, maka pengukuran yang dilakukan bukan secara eksak/matematis yang bersifat pasti. Pengukuran secara eksak/matematis tidak 
mungkin dilakukan dalam penilaian kinerja, karena objeknya adalah perilaku manusia yang unik, rumit dan kompleks. Kesulitan melakukan penilaian secara eksak/matematis, terutama disebabkan oleh banyaknya aspek-aspek psikis atau proses mental dan sosial, yang tidak dapat dinyatakan secara kuantitatif dalam bentuk angka, jumlah atau bilangan. Penilaian kinerja sulit untuk melepaskan kegiatannya dari aspek emosional para pekerja sebagai manusia.

Aspek ini sangat mudah menimbulkan perasaan tersinggung, karena sifat sensitif manusia, terutama apabila hasil penilaian kinerja dirasakan tidak sesuai dengan kegiatan atau usaha yang telah dilakukannya. Dalam keadaan seperti itu, penilaian kinerja dapat dianggap sebagai kegiatan intervensi organisasi terhadap kehidupan pekerja sebagai individu yang memiliki hak-hak asasi yang dilindungi. Penilaian kinerja sering menyentuh kelemahan atau kekurangan individu. Untuk itu, para penilai yang mewakili organisasi dalam melakukan penilaian kinerja berkewajiban untuk bertindak hati-hati dengan tidak mengabaikan hak-hak asasi para pekerja sebagai manusia, apalagi pengawas sebagai profesional.

Tugas penilik satuan pendidikan dalam melakukan pembimbingan dan pelatihan profesional pengawas dalam melaksanakan tugas pokoknya yaitu merencanakan, melaksanakan, dan menilai proses pembelajaran/ pembimbingan, dan membina tenaga kependidikan lainnya baik pada satuan pendidikan maupun melalui Kelompok Kerja Pengawas, Musyawarah Pengawas Mata Pelajaran dan atau bentuk lain yang dapat meningkatkan kompetensi pengawas dan tenaga kependidikan lainnya. Untuk memperoleh pemahaman bersama tentang pelaksanaan tugas pengawas satuan pendidikan sesuai dengan amanat peraturan perundangundangan, maka perlu disusun satu model pola pembimbingan terhadap pengawas melalui model perangkat pengawasan baik pengawasan akademik maupun pengawasan manajerial.

Dalam rangka implementasi tugas pengawasan sesuai dengan Permendiknas Nomor 39 tahun 2009 dan Permendiknas Nomor 21 tahun 2007, maka diperlukan adanya pengawas pendidikan yang memiliki kemampuan menejerial, yaitu (1) pengawas sekolah yang mampu melakukan supervisi/kepengawasan pendidikan, (2) pengawas pendidikan yang mampu atau memiliki kompetensi sebagai pengawas, (3) pengawas pendidikan memiliki kinerja yang baik, (4) pengawas pendidikan yang mampu menyusun program kerja kepengawasan, dan (5) pengawas pendidikan yang mampu menilai kinerja pendidikan.
Dalam melaksanakan tugas pokoknya, penilik harus mampu memotivasi, mendorong, menggalang, mengarahkan, membimbing, mensupervisi seluruh pendidik dan tenaga kependidikan yang menjadi tanggung jawabnya. Fungsinya yang cukup strategis itu akan dapat meningkatkan proses pembelajaran dan bimbingan yang dilakukan oleh pengawas, sehingga proses pendidikan akan berlangsung secara efektif.

Kinerja penilik merupakan fungsi dari interaksi antara kemampuan dan motivasi. Apabila kemampuan dan/atau motivasi seseorang tidak sesuai dengan yang dibutuhkan, maka akan berdampak negatif terhadap kinerjanya (Robbins, 2005: 192). Berdasarkan pendapat tersebut, maka kemampuan, termasuk kecerdasan dan keterampilan, perlu dipertimbangkan di samping motivasi pengawas, apabila diharapkan akurasi ramalan terhadap kinerja penilik.

Kabupaten Gorontalo memiliki 26 penilik pendidikan nonformal. Dilihat dari orientasi tugas pokok dan fungsinya, tenaga penilik adalah tenaga yang bertugas melakukan pemantauan evaluasi, supervisi, dan pelaporan berkaitan dengan kegiatan-kegiatan PNF di wilayah pemerintah Kabupaten Gorontalo.

Dalam kenyataannya, keberadaan tenaga kependidikan PNF khuusnya penilik PLS, berdasarkan hasil kajian empiris menunjukkan indikasi sebagai berikut.

Pertama, secara kuanogiratif, rasio jumlah tenaga kependidikan (penilik PLS) di semua level dan jenjang dengan luasnya wilayah kerja, sasaran, dan garapan program tidak seimbang.

Kedua, adanya suasana psikososial yang tidak kondusif, seseorang memasuki jabatan sebagai penilik PLS. Seseorang yang mengaku jabatan tersebut, merasa terpinggirkan, dan terbuang bahkan dirasakan sebagai sebuah hukuman.

Ketiga, dilihat dari proposi kualifikasi akademik maupun administratif, tenaga penilik pendidikan luar sekolah yang ada, penataannya belum mengacu pada standar yang ideal. Penilik PLS dengan kualifikasi sarjana PLS tidak mencapai 15\%. Di sisi lain, dengan kebijakan otonomi daerah, penilik baru yang berlatar belakang kepala sekolah (SD) rata-rata mencapai $60 \%$, mereka belum memahami tupoksinya.

Keempat, belum adanya standarisasi kompetensi tenaga profesional penilik PLS yang dibuktikan dan diselenggarakan melalui sistem lisensi dan sertifikasi.

Kelima, belum adanya standarisasi sistem rekruitmen tenaga penilikpendidikan luar sekolah.

Keenam, sistem karier (carier planning), sebagai acuan bagi peningkatan kinerja tenaga kependidikan (penilik PLS), tidak jelas. 
Ketujuh, masih terjadinya missmanagement dalam pelaksanaan TUPOKSI tenaga kependidikan (penilik PLS), karena belum adanya tenaga khusus (eksekutor/impelmentator) yang profesional menangani dari mulai pembentukan, pengelolaan, evaluasi, dan tindak lanjut program-program PLS.

Kedelapan, masih terjadi kesimpangsiuran (mis- perception) penamaan dan kompetensi tenaga kependidikan (penilik PLS).

Kesembilan, lemahnya penghargaan (reward), dengan tugas pokok dan fungsi cukup besar dan luas, namun bila dibandingkan dengan sistem penghargaan terhadap penilik TK/SD masih belum seimbang.

\section{KAJIAN TEORETIS}

\section{Pengertian Kepengawasan}

Penilik adalah salah satu tenaga kependidikan, yang bertugas memberikan pengawasan agar tenaga kependidikan dapat menjalankan tugasnya dengan baik. Penilik berdasarkan keputusan Menteri Negara Pendayagunaan Aparatur Negara Nomor 118/1996 adalah pegawai negeri sipil yang diberi tugas, tanggung jawab dan wewenang secara penuh oleh pejabat yang berwenang untuk melakukan pengawasan dengan melaksanakan penilaian dan pembinaan dari segi teknis pendidikan dan administrasi pada satuan pendidikan pra sekolah, dasar, dan menengah (Siahaan, 2006:10). Peraturan Pemerintah dan Keputusan Menteri Pendayagunaan Aparatur Negara tersebut, dapat dikatakan bahwa kedudukan penilik sangat strategis dan akan mempengaruhi mutu pendidikan secara keseluruhan. Penilik bersifat fungsional dan bertanggung jawab terhadap terjadinya proses pembelajaran, pendidikan dan bimbingan di lingkungan persekolahan pada berbagai jenjang dan jenis pendidikan. Fungsinya yang cukup strategis itu akan dapat meningkatkan proses pembelajaran dan bimbingan yang dilakukan oleh penilik, sehingga proses pendidikan akan berlangsung secara efektif.

Sebagai tenaga kependidikan, penilik membutuhkan bantuan tenaga penilik. Penilik merupakan personel yang selalu berhadapan dengan berbagai hal dimana dirinya tidak dapat memecahkan masalah secara menyeluruh tanpa mendapat bantuan dari pihak lainnya, terutama dari penilik. Penilik selalu berhadapan dengan situasi yang setiap saat berubah, seperti kurikulum, tuntutan masyarakat, pemenuhan kebutuhan hidupnya, dan lain sebagainya. Hal tersulit yang dihadapi penilik adalah menghadapi perubahan tuntutan masyarakat, yaitu tuntutan terhadap perubahan yang cukup deras dari masyarakat sehingga membutuhkan perubahan kurikulum. Dengan situasi itu, adakalanya penilik tidak siap menghadapi seorang diri tanpa ada bantuan dari pihak lainnya.

Situasi itu tidak kondusif bagi pelaksanaan tugas penilik, ditambah lagi karena sistem pembinaan penilik maupun oleh karena faktor penilik itu sendiri. Dalam konteks inilah penilik sebagai unsur tenaga bantuan yang bertugas memberikan layanan kepada tenaga kependidikan, relevan dan sangat dibutuhkan.

Penilik merupakan salah satu komponen yang memiliki peran penting dalam peningkatan mutu pendidikan nonformal. Dengan adanya pengawasan yang dilakukan penilik (supervisor) akan menumbuhkan semangat dan motivasi mengajar penilik dengan cara memperbaiki segala jenis dan bentuk kekurangkekurangannya dalam proses belajar mengajar. Proses bantuan itu dapat dilakukan secara langsung kepada penilik itu sendiri, maupun secara tidak langsung.

Pengertian pengawasan menurut beberapa ahli dalam Siahaan (2006:14) adalah sebagai berikut.

1. Supervise adalah suatu program inservice-education dan usaha memperkembangkan kelompok secara bersama-sama.

2. Supervise adalah suatu usaha menstimulir, mengkoordinasi dan membimbing secara kontinu pertumbuhan pendidik, baik secara individu maupun secara kolektif agar mampu meningkatkan mutu dan kinerjanya.

\section{Tujuan kepengawasan}

Tujuan penilik adalah memberikan berbagai alternatif pemecahan masalah dalam pembelajaran. Bila terjadi sesuatu yang timbul atau mencuat ke permukaan yang dapat mengganggu kosentrasi proses belajar mengajar, maka kehadiran penilik bersifat fungsional untuk melakukan perbaikan. Oleh karena itu, pemberdayaan penilik diperlukan untuk meningkatkan fungsinya sebagai motivator, fasilitator, dan sekaligus katalisator pengajaran. Supervisi penting di dalam kegiatan pembelajaran karena mengikuti prinsip-prinsip administrasi yang mengarah kepada pencapaian tujuan, yaitu pembentukan manusia sebagai pribadi dan individu.

Pengawasan diperlukan dalam peningkatan mutu pendidikan nonformal. Asumsi ini didasarkan atas kenyataan bahwa setiap orang bekerja memerlukan penghargaan, dorongan dan lain sebagainya dari orang lain. Jika pada saat ini seseorang malas, tetapi karena 
didorong orang lain, termotivasi kembali untuk melakukan sesuatu. Tugas penilik pendidikan, salah satunya adalah memberikan dorongan agar tenaga kependidikan, baik penilik, kepala dan personel lainnya, termotivasi untuk berkinerja.

Siahaan (2006:16) menegaskan lebih lengkap lagi tujuan lebih supervisi, menurutnya terdapat tiga tujuan supervisi, yaitu.

\section{Pengawasan Berkualitas}

Dalam supervise, penilik bisa memonitor kegiatan proses belajar mengajar di kelas. Kegiatan memonitor ini bisa dilakukan melalui kunjungan penilik ke kelaskelas saat pamong atau tutor sedang mengajar, percakapan pribadi dengan pamong atau tutor, teman sejawatnya, maupun dengan sebagai warga belajarnya.

\section{Pengembangan Profesional}

Dalam supervisi pengajaran, penilik bisa membantu pamong atau tutor mengembangkan kemampuannya dalam memahami pengajaran, kehidupan kelas, mengembangkan keterampilan mengajarnya, dan menggunakan kemampuannya melalui teknik-teknik tertentu. Teknik-teknik tersebut bukan saja bersifat individual, melainkan juga bersifat kelompok.

\section{Peningkatan Motivasi Pamong atau tutor}

Dalam supervisi pengajaran, penilik bisa mendorong pamong atau tutor menerapkan kemampuannya dalam melaksanakan tugas-tugas pengajaran, mendorong pamong atau tutor mengembangkan kemampuan sendiri, serta mendorong pamong atau tutor agar memiliki perhatian yang sungguh-sungguh (commitment) terhadap tugas dan tanggung jawabnya. Pendek kata, melalui supervisi pengajaran, penilik bisa menumbuhkan motivasi kerja pamong atau tutor.

Supervisi pengajaran yang baik adalah supervisi pengajaran yang merefleksi multitujuan yang tersebut di atas. Tidak ada keberhasilan bagi supervisi jika hanya memperhatikan salah satu tujuan tertentu dengan menyampingkan dengan tujuan lainnya. Hanya dengan merefleksi dengan ketiga tujuan inilah supervisi pengajaran akan mampu mengubah perilaku mengajar pamong atau tutor. Pada gilirannya nanti akan merubah perilaku pamong atau tutor kearah yang lebih kualitas dan akan menimbulkan perilaku murid yang lebih baik.

Alfonso, Firth, dan Neville (1981:23) menggambarkan sistem pengaruh perilaku supervisi pengajaran sebagai berikut.

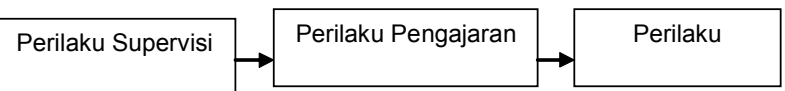

Gambar 1. Ruang Lingkup Perilaku Pengawasan
Sumber: Alfonso, Firth, \& Neville (1981)
Bagan di atas menjelaskan bahwa perilaku supervisi pengajaran secara langsung berhubungan dan pengaruh terhadap perilaku pamong atau tutor. Ini berarti melalui supervisi pengajaran, penilik mempengaruhi perilaku mengajar pamong atau tutor, sehingga perilakunya semakin baik dalam mengelola proses belajar mengajar. Selanjutnya, perilaku mengajar pamong atau tutor yang baik itu akan mempengaruhi perilaku belajar peserta didik. Dengan demikian bisa dikatakan, bahwa tujuan akhir supervisi pengajaran adalah terbinanya perilaku belajar peserta didik yang lebih baik.

\section{Fungsi-fungsi Kepengawasan}

Menurut Rohani (1991: 72) terdapat delapan fungsi pengawas, yaitu (1) mengkoordinasikan semua usaha PNF, (2) memperlengkapi kepemimpinan PNF, (3) memperluas pengalaman tutor, (4) menstimulasi usaha-usaha yang kreatif, (5) memberikan fasilitas penilaian yang terus menerus, (6) menganalisis situasi belajar dan mengajar, (7) memberikan pengetahuan/ skill setiap anggota/staf, dan (8) membantu meningkatkan kemampuan mengajar tutor.

Keberadaan penilik pada lembaga pendidikan nonformal adalah memberikan dorongan dan bantuan kepada tutor dalam menyelesaikan segala jenis dan bentuk persoalan yang muncul dalam pelaksanaan pengajaran. Penilik pendidikan adalah mitra kerja tutor dalam pelakasanaan peningkatan mutu pembelajaran. Oleh karena itu, penilik tidak perlu ditakuti oleh tenaga kependidikan. Namun, ada asumsi yang berkembang bahwa keberadaan penilik adalah untuk mencari kesalahan yang dilakukan pendidik. Asumsi ini merupakan asumsi yang keliru dan tidak berdasar sama sekali, walaupun terdapat perilaku penilik yang hanya mencaricari kesalahan tenaga kependidikan di lingkungan sekolah, itu bukanlah watak, karakter atau fungsi penilik, tindakan itu terjadi bersifat individual dari seorang penilik dan diyakini hanya bersifat kasuistik.

Menurut Masaong (2011: 19), prinsip-prinsip kepengawasan adalah sebagai berikut (1) prinsip ilmiah, (2) demokratis yang menjunjung tinggi asas musyawarah, (3) kooperatif/kemitraan, serta (4) kontruktif dan kreatif.

Berdasarkan uraian, di atas maka tugas pengawas mencakup, (1) inspecting (mensupervisi), (2) advising (memberi nasehat), (3) monitoring (memantau), (4) reporting (membuat laporan), (5) coordinating (mengkoordinir), dan (6) performing leadership dalam arti memimpin dalam melaksanakan kelima tugas pokok tersebut.

\section{Kinerja Penilik dalam Tupoksi}

Kinerja penilik merupakan fungsi dari interaksi antara kemampuan dan motivasi. Apabila kemampuan 
dan/atau motivasi seseorang tidak sesuai dengan yang dibutuhkan, maka akan berdampak negatif terhadap kinerjanya (Sinaulan, 2007: 56). Berdasarkan pendapat tersebut, maka kemampuan, termasuk kecerdasan dan keterampilan, perlu dipertimbangkan di samping motivasi pekerja, apabila diharapkan akurasi ramalan terhadap kinerja pekerja. Di samping kemampuan dan motivasi, kepada penilik juga perlu diberi kesempatan untuk berkinerja sesuai dengan yang diharapkan. Hal ini dikarenakan, meskipun seorang penilik mempunyai motivasi dan kemampuan yang memadai, mungkin terdapat kendala-kendala yang merintanginya.

Drucker (1977: 237-242) mengemukakan bahwa kinerja dalam pengertian yang luas, seperti diuraikan di atas, mempunyai lima dimensi, yaitu.

\section{Dimensi fisiologis}

Manusia akan bekerja dengan baik, bila berada dalam konfigurasi operasional bersama tugas dan ritme kecepatan sesuai dengan keadaan fisiknya.

2. Dimensi psikologis

Bekerja merupakan ungkapan kepribadiannya karena seseorang yang mendapatkan kepuasan kerja akan berdampak pada kinerja yang lebih baik.

3. Dimensi sosial

Bekerja dapat dipandang sebagai ungkapan hubungan sosial di antara sesama individu.

4. Dimensi ekonomi

Bekerja adalah kehidupan bagi seseorang, imbalan jasa yang tidak sepadan dapat menghambat individu dalam berprestasi, demikian pula sebaliknya.

5. Dimensi keseimbangan

Keseimbangan antara apa yang diperoleh dari pekerjaan dengan kebutuhan hidup, akan memacu seseorang untuk berusaha lebih giat guna mencapai keseimbangan. Ketidakseimbangan dapat menimbulkan konflik yang dapat menurunkan kinerja.

Perencanaan kinerja adalah sebuah proses di mana pekerja dan manajer bekerja sama untuk menentukan apa yang seharusnya dilakukan oleh pekerja pada periode waktu tertentu yang akan datang, dan apa yang diformulasikan sebagai kinerja yang sukses. Bagian-bagian penting dari diskusi perencanaan kinerja adalah (a) mengidentifikasi bantuan yang akan disediakan manajer; (b) mengidentifikasi kendala-kendala yang menghambat pencapaian, serta cara-cara mengatasinya, dan (c) mengembangkan pemahaman bersama tentang arti penting relatif dari tugas-tugas kerja (prioritas) dan tingkat kewenangan.

Dalam perencanaan kinerja dapat digunakan "Manajemen Berdasarkan Sasaran (Management By Objectives = MBO)" (Bacal, 1989:64-65). Management By Objectives merupakan sistem manajemen yang memasukkan partisipasi dalam pengambilan keputusan, penyusunan tujuan, dan umpan-balik sasaran.

Berdasarkan rumusan pengertian di atas, maka prinsip-prinsip kinerja memiliki standar kinerja mempunyai dua fungsi, yaitu.

a. Standar dijadikan target oleh pekerja.

Tantangan atau kebanggaan dalam mencapai sasaran dapat memotivasi pekerja. Apabila standar dapat dicapai, pekerja akan merasa berprestasi yang dapat memberikan kepuasan bagi pekerja.

b. Standar merupakan kriteria untuk menentukan keberhasilan kerja.

Standar sangat diperlukan untuk mengendalikan kinerja. Tanpa standar, tidak ada sistem kendali yang dapat menilai suatu kinerja.

Unsur-unsur tersebut sangat aplikatif untuk diterapkan pada manajemen sekolah, artinya, Total Quality Management yang diterapkan di sekolah harus memfokuskan pada kepuasan anak didik, orang tua, dan masyarakat luas, termasuk pamong atau tutor, kepala sekolah beserta seluruh staf sekolah, dan untuk itu perlu dilakukan pengukuran yang akurat terhadap setiap variabel penting, termasuk kinerja pamong atau tutor, serta terbinanya hubungan kerja atas kepercayaan dan kerjasama yang harmonis.

Di samping itu, karena sekolah merupakan suatu sistem sosial terbuka, yang harus berhadapan dengan lingkungan yang selalu berkembang dinamis, maka kualitas pamong atau tutor sebagai salah satu subsistem, harus selalu diupayakan pengembangan yang berkelanjutan, sesuai dengan kebutuhan dan tuntutan masyarakat.

\section{METODOLOGI PENELITIAN}

Penelitian ini dilaksanakan dengan menggunakan pendekatan fenomenologis dengan jenis penelitian kualitatif. "Pendekatan fenomenologis dalam penelitian kualitatif berusaha untuk memahami arti peristiwa dan kaitannya terhadap orang-orang biasa dalam situasi tertentu" (Moleong, 2001; 1). Penelitian kualitatif menurut Bogdan (dalam Tuloli, 2002;1) adalah suatu strategi yang digunakan untuk meneliti masalah-masalah yang tidak dapat ditangani dengan prosedur-prosedur statis.

Kehadiran peneliti berperan sebagai instrumen utama, dalam hal ini peneliti, berkomunikasi langsung 
dengan situasi orang-orang yang diteliti. Dalam melakukan penelitian, peneliti berlaku wajar baik dalam hal berkomunikasi maupun berkunjung.

Penelitian ini dilaksanakan di Kabupaten Gorontalo dengan setting penelitian Kinerja Penilik PNF dalam pelaksanaan program PNF. Nasution (Tuloli, 2002: 31) menyatakan bahwa sumber data bisa berupa orang (informan) yang diwawancarai, peristiwa, hal atau situasi yang diobservasi. Dalam hal ini, peneliti menetapkan beberapa sumber data, antara lain.

1. Sumber utama yaitu penilik PNF yang bertugas pada empat Kecamatan di wilayah Kabupaten Gorontalo yang berjumlah lima orang Penilik PNF, dan tiga orang organisasi lkatan Penilik Indonesia (IPI) Kabupaten Gorontalo.

2. Sumber teoretis, sejumlah literatur yang ada kaitannya dengan masalah yang dikaji.

3. Sumber informasi adalah Kepala Cabang Dinas Pendidikan Kecamatan, Ikatan Penilik Indonesia (IPI) Kabupaten Gorontalo.

Prosedur pengumpulan data dalam penelitian ini adalah sebagai berikut.

\section{Wawancara.}

Wawancara dilakukan dalam rangka mengetahui dan mengkaji apa yang menjadi fokus dalam penelitan ini. Wawancara yang dilakukan adalah wawancara bebas, dalam hal ini peneliti mengajukan pertanyaanpertanyaan tanpa menggunakan daftar pertanyaan tetapi hanya berpedoman pada garis-garis besar pertanyaan yang sudah disiapkan. Pertanyaan akan berkembang pada saat proses wawancara berlangsung.

\section{Observasi.}

Observasi adalah melakukan pengamatan secara langsung terhadap objek yang diteliti. Kegiatan ini memberikan kemungkinan bagi peneliti untuk melihat dan mengamati sendiri kejadian-kejadian sebenarnya yang terjadi.

\section{Studi Dokumen}

Teknik ini dilakukan dengan mencatat data yang terdapat dalam dokumen. Hasil studi dokumen ini akan lebih memperjelas dan melengkapi informasi yang diperoleh melalui wawancara dan observasi.

Proses analisis data dilakukan dengan mengikuti tahap-tahap sebagai berikut.

\section{Reduksi Data.}

Pada tahap reduksi data dilakukan pemilihan, pemusatan perhatian pada penyederhanaan, pengabstraksian, dan transformasi "data kasar" yang belum nampak jelas maknanya (Tuloli, 2002;91).

\section{Penyajian Data.}

Kegiatan yang dilakukan pada tahap ini adalah mengumpulkan data yang telah diseleksi dan disederhanakan pada tahap reduksi, selanjutnya dikelompokkan menjadi satuan-satuan data.

3. Penarikan Kesimpulan.

Kegiatan ini adalah menyimpulkan data hasil penelitian sesuai dengan permasalahan dan tujuan penelitian.

Uji keabsahan data ini meliputi kegiatan-kegiatan antara lain.

1. Uji Kredibilitas.

Tuloli (2002; 39) mengemukakan bahwa "Uji kredibilitas dapat dilakukan melalui kegiatan sebagai berikut.

a. Triangulasi, mengecek kebenaran data yang sudah ada pada sumber atau informan lain dengan cara dan pada waktu yang lain.

b. Mengkonfirmasikan kembali kepada informan yang pernah diwawancarai mengenai keterangan atau data yang pernah diberikannya pada waktu lalu.

2. Dependabilitas.

Dependablitas atau kebergantungan ini bermaksud untuk melihat konsistensi data yang diperoleh pada peristiwa yang sama dalam waktu yang berlainan.

\section{HASIL PENELITIAN}

Berdasarkan penelitian yang relevan sebagaimana tergambar dalam makalah yang ditulis Husain (2010:12) dapat dilihat dari tingkat komplektisitas penilik dari kegiatannya, dapat dipahami bahwa tugas seorang penilik PNF merupakan tugas yang berat, karena selain sasaran kegiatannya luas dan tidak terbatas, tugas sebagai penilik juga senantiasa berkaitan dengan masyarakat yang memiliki tingkat pendidikan yang minim bahkan belum pernah tersentuh oleh pendidikan. Oleh karena itu, dalam hal ini dituntut kinerja dan profesionalisme seorang penilik. Kinerja yang dimaksud adalah kualitas kerja dari seorang penilik yang diserah- kan tanggung jawab untuk melaksanakan tugas tertentu di mana dalam hal ini yang bersangkutan harus siap menjalankan tugasnya yakni mengawasi/mengontrol semua kegiatan PNF, memenuhi kewajiban dengan melaporkan setiap perkembangan yang terjadi dalam lingkungan kerjanya kepada pihak atasan serta senantiasa memberikan binaan kepada warga masyarakat sehingga program PNF yang dibinanya mampu mencapai target yag telah ditetapkan.

\section{Deskripsi Temuan Penelitian}

Fokus penelitian ini adalah kinerja penilik PNF dalam pelaksanaan tugas yang terdapat pada empat 
Kecamatan di Kabupaten Gorontalo. Indikator kinerja penilik diidentifikasi melalui tugas pokok dan fungsinya yang mengacu pada asfek perencanaan, pengorganisasian/pelaksanaan, pengawasan, dan evaluasi. Aspek yang diidentifikasi mengacu pada upaya penilik PNF dalam mengembangkan kinerja pelaksanaan tupoksinya. Data diperoleh dari penilik PNF pada empat kecamatan di Kabupaten Gorontalo, dan melalui organisasi Ikatan Penilik Indonesia (IPI) Provinsi Gorontalo. Sebagai sumber data diperoleh dari penilik PNF sejumlah lima orang dan satu orang pengurus Ikatan Penilik Indonesia (IPI) Provinsi Gorontalo serta dua orang pengurus Ikatan Penilik Indonesia (IPI) Kabupaten Gorontalo. Teknik yang digunakan melalui wawancara, observasi, studi dokumen program, dan kegiatan penilik serta organisasi IPI.

Adapun gambaran kinerja penilik PNF dalam pelaksanaan tupoksinya sesuai data penelitian diakumulasi dalam pokok-pokok uraian sebagai berikut.

Pertama, perencanaan. Perencanaan mengacu pada kemampuan penilik untuk menyusun rencana kegiatan-kegiatan PNF baik secara tahunan maupun triwulan. Terkait dengan kegiatan tersebut, peneliti menanyakan "apakah Anda sebagai penilik PNF membuat perencanaan kegiatan PNF untuk masyarakat?"

Dari jawaban kelima informan dapat disimpulkan bahwa pada umumnya para penilik PNF pada empat kecamatan ini belum pernah menyusun rencana kegiatan PNF. Pada umumnya tugas penilik hanya untuk mengembangkan program-program PNF yang sudah ada sebelumnya, atau menunggu program PNF dari Dinas kabupaten.

Kedua, pengorganisasian/pelaksanaan. Pengorganisasian/pelaksanaan mencakup kemampuan penilik untuk mengorganisasikan kegiatan-kegiatan yang akan dilaksanakan, sedangkan pelaksanaan lebih ditekankan pada kemampuan dan tanggung jawab penilik dalam melaksanakan kegiatan-kegiatan PNF. Dalam hubungan ini pertanyaan yang diajukan adalah " apakah Anda sebagai Penilik PNF mampu mengorganisasikan kegiatan-kegiatan PNF?"

Secara umum, kelima informan penilik dan pengurus IPI memberikan jawaban yang hampir sama, bahwa pada dasarnya mampu mengorganisasikan kegiatan-kegiatan PNF di masyarakat. Dari konteks jawaban-jawaban informan dapat dikemukakan bahwa dari lima penilik yang bertugas pada empat kecamatan, dua penilik ternyata sudah mampu melaksanakan tugasnya dengan penuh tanggung jawab, sedangkan tiga penilik lainnya pada dasarnya dinilai sudah bertanggung jawab akan tetapi belum berhasil.

Ketiga, pengawasan. Pengawasan terkait dengan kemampuan peran penilik dalam mengawasi pelaksanaan kegiatan yang telah diprogramkan di masyarakat. Melalui pengawasan dapat diketahui apakah program yang telah diberikan bisa berjalan dengan baik atau tidak. Pertanyaan yang diajukan adalah "apakah Anda sebagai Penilik PNF senantiasa mengawasi kegiatan pendidikan nonformal?"

Memperhatikan jawaban-jawaban yang disampaikan oleh informan, dapat disimpulkan bahwa pada dasarnya empat penilik telah mampu melakukan pengawasan, namun pelaksanaannya belum optimal karena belum dilakukan secara intensif, sementara satu penilik dinilai belum mampu melakukan pengawasan terhadap kegiatan-kegiatan PNF.

Dari jawaban informan dapat dikemukakan bahwa pada umumnya para penilik PNF pada empat kecamatan tersebut belum mampu melaksanakan pembinaan dan memberikan bimbingan kepada masyarakat, kondisi ini menunjukkan bahwa kemampuan penilik dalam melakukan bimbingan dan pembinaan kepada masyarakat belum optimal.

Keempat, evaluasi. Evaluasi adalah kegiatan untuk menilai apakah program yang telah dilaksanakan berhasil atau tidak. Terkait dengan indikator tupoksi ini pertanyaan yang diajukan adalah "apakah Anda sebagai Penilik PNF selalu melakukan evaluasi terhadap kegiatan-kegiatan PNF di masyarakat?"

Terhadap pertanyaan ini, kelima informan memberikan jawaban yang sama bahwa selama ini mereka selalu melakukan evaluasi untuk menilai apakah program-program yang mereka laksanakan itu berhasil atau tidak.

\section{Pembahasan dan Analisis}

Kinerja dapat diartikan sebagai kualitas kerja. Kualitas kerja ini lebih mengacu pada (1) melakukan, menjalankan, melaksanakan; (2) memenuhi atau menjalankan kewajiban; (3) melaksanakan atau menyempurnakan tanggung jawab; dan (4) melakukan sesuatu yang diharapkan oleh seseorang atau mesin. Kinerja juga dapat dikatakan sebagai prestasi kerja (performance).

Dengan demikian, dapat disimpulkan bahwa kinerja terkait dengan bagaimana cara melakukan suatu pekerjaan, bagaimana mencapai hasil sesuai dengan yang diinginkan oleh suatu organisasi yang disesuaikan dengan tugas dan tanggung jawab masing-masing.

Dalam proses pencapaiannya, kinerja juga dipengaruhi oleh beberapa faktor. Faktor-faktor yang mempengaruhi kinerja yaitu (1) kemampuan, (2) motivasi, (3) dukungan yang diterima, (4) keberadaan pekerjaan yang dilakukan, dan (5) hubungan dengan organisasi. 
Berdasarkan keputusan Menpan No.15/KEP/ M.PAN/3/2002, penilik adalah jabatan fungsional dan jabatan karier yang hanya dapat diduduki oleh PNS. Penilik mempunyai tugas, tanggung jawab, wewenang, dan hak untuk melakukan pemantauan, penilaian, dan bimbingan terhadap penyelenggaraan pendidikan luar sekolah. Kedudukan penilik adalah sebagai pelaksana teknis fungsional penilikan pendidikan luar sekolah pada Dinas Pendidikan Kabupaten/Kota atau dinas lainnya yang bertanggung jawab di bidang pendidikan luar sekolah. Penilik diangkat oleh bupati/walikota. Meskipun berkedudukan pada tingkat kabupaten/kota, namun pelaksanaan tugas penilik adalah pada tingkat kecamatan atau desa (www.jugaguru.com).

Peran penilik dalam pendidikan nonformal sebagaimana disebutkan dalam PP No. 19 Tahun 2005 adalah melakukan pengawasan terhadap pelaksanaan program pendidikan nonformal. Lubis (Depdiknas, 2007: 37) menyatakan bahwa "pengawasan adalah kegiatan manajer yang mengusahakan agar pekerjaan-pekerjaan terlaksana sesuai dengan rencana yang ditetapkan dan atau dengan hasil yang dikehendaki". Artinya, bahwa pengawasan adalah kegiatan untuk mengetahui seberapa jauh pencapaian hasil dari apa yang telah direncanakan. Melalui pengawasan dapat dilakukan perbaikan dan penyempurnaan terhadap kegiatankegiatan yang belum sempat terlaksana maupun tujuantujuan yang belum tercapai.

Itulah sebabnya, dapat dikatakan bahwa standar kinerja sangat diperlukan dalam perencanaan kinerja. Pimpinan membutuhkan informasi tentang standar kinerja, baik dalam artian tingkat kuantitas maupun kualitas pada setiap tugas, karena pimpinan akan menggunakannya untuk menilai para bawahannya.

Standar kinerja menetapkan apa yang harus dikerjakan, dan ukuran seberapa baik dikerjakannya. Apabila standar kinerja yang dikomunikasikan kepada pekerja lebih jelas, maka proses review akan lebih akurat dan adil.

Standar kinerja mempunyai dua fungsi, yaitu.

1. Standar dijadikan target oleh pekerja.

Tantangan atau kebanggaan dalam mencapai sasaran dapat memotivasi pengawas. Apabila standar dapat dicapai, pengawas akan merasa berprestasi yang dapat memberikan kepuasan bagi pengawas.

2. Standar merupakan kriteria untuk menentukan keberhasilan kerja.

Standar sangat diperlukan untuk mengendalikan kinerja. Tanpa standar, tidak ada sistem kendali yang dapat menilai suatu kinerja.

Berkaitan dengan Standar Kompetensi seorang penilik, Depdiknas (2007: 37) menyatakan bahwa "Standar adalah kriteria/norma yang harus dimiliki penilik, sedangkan kompetensi adalah kemampuan dasar yang harus dimiliki oleh penilik". Jadi, standar kompetensi adalah kriteria atau norma dan kemampuan yang harus dimiliki oleh penilik. Terkait dengan standar kompetensi, dalam PP Nomor 19 Tahun 2005 disebutkan bahwa "Seorang penilik harus memiliki empat kemampuan yakni kompetensi pedagogik dan andragogi, kompetensi profesional, kompetensi kepribadian, serta kompetensi sosial".

Kompetensi yang harus dikuasai oleh penilik perlu dinyatakan sedemikan rupa agar dapat dinilai secara objektif berdasarkan kinerjanya, dengan bukti penguasaan pada aspek pedagogi dan andragogi, kepribadian dan sosial, serta profesional. Dalam menetapkan kriteria penilaian, pertama, perlu adanya penetapan parameter untuk mengukur kompetensi yang dimiliki, kedua, perlu ditetapkan poin pada setiap parameter yang merupakan standar yang dapat diterima. Standarisasi kompetensi dirancang sebagai suatu standar yang bersifat nasional yang mengarah pada peningkatan kualitas penilik dan pola pembinaan penilik yang terstruktur dan sistematis untuk digunakan sebagai acuan pengembangan sistem uji kompetensi, di mana kebijakan umum dan teknis penyelenggaraan mengacu pada suatu prosedur baku.

Peraturan Pemerintah tentang Standar Nasional Pendidikan No. 19 tahun 2005, menuntut adanya standar kompetensi dan kualifikasi pendidik dan tenaga kependidikan baik formal mapun nonformal. Kenyataan yang ada menunjukkan bahwa untuk pendidikan nonformal belum memiliki standar nasional yang baku khususnya tentang kompetensi PTK-PNF termasuk penilik. Beberapa permasalahan yang terkait dengan belum adanya standar kompetensi yang dirasakan saat ini adalah (1) tidak adanya keseragaman tingkat kemampuan dan kualitas, (2) tidak dapat membuat suatu alat ukur yang akurat untuk mengetahui kompetensi penilik, (3) pengembangan kemampuan dan pembinaan yang dilakukan bagi penilik tidak berdasarkan pada apa yang perlu ditingkatkan, dan (4) masih rendahnya tingkat kesejahteraan dari para penilik.

\section{Perencanaan}

Perencanaan sangat diperlukan agar suatu program/kegiatan bisa dilaksanakan dengan benar. Melalui perencanaan yang matang, suatu program/ kegiatan bisa dilaksanakan secara terstruktur dan terkendali. Perencanaan adalah usaha sadar dan pengambilan keputusan yang telah diperhitungkan secara matang tentang hal-hal yang akan dikerjakan 
di masa depan, dalam, dan oleh suatu organisasi dalam rangka pencapaian tujuan yang telah ditetapkan. Perencanaan sangat penting dilakukan karena, (1) dalam perencanaan dapat digariskan tujuan organisasi sehing-ga geraknya dapat diarahkan, (2) dengan perencanaan semua aktivitas dapat diarahkan ketujuan yang telah ditetapkan, dan (3) dapat diperoleh tindakan yang tepat terkoordinasi dari berbagai unit kerja" (Depdiknas, 2007: 32).

Penilik PNF sebagai salah satu tenaga fungsional di lapangan harus mampu membuat perencanaan terhadap seluruh kegiatan-kegiatan yang akan diprogramkan bagi masyarakat. Perencanaan disusun berdasarkan kriteria kebutuhan yang ada di masyarakat, sehingga pelaksanaannya akan berjalan sesuai dengan hasil yang diharapkan. Dengan demikian, kegiatan yang akan diprogramkan kepada masyarakat akan selalu berbeda dari periode satu ke periode lainnya.

Memperhatikan data informan terkait dengan indikator perencanaan yang perlu dilakukan oleh Penilik PNF, diperoleh suatu kesimpulan bahwa dari lima penilik PNF pada empat kecamatan sebagai lokasi penelitian ini belum sepenuhnya mampu menyusun suatu rancangan kegiatan PNF untuk masyarakat. Sebagian besar dari penilik hanya berperan sebagai pengembang program yang telah ada, kondisi ini mengakibatkan banyaknya kegiatan-kegiatan PNF yang tidak sesuai dengan kebutuhan masyarakat yang dirasakan dari empat kecamatan tersebut. Sebagai contoh, melaksanakan pembuatan percontohan program PLS, melaksanakan pengendalian mutu program PLS, dan melaksanakan pelayanan Informasi Program Pendidikan Luar Sekolah

\section{Pengorganisasian/Pelaksanaan}

Pengorganisasian berkaitan dengan upaya melibatkan komponen masyarakat, melakukan pembagian kerja, serta mengelompokan jenis-jenis kegiatan yang disesuaikan dengan kebutuhan kelompok-kelompok sasaran, sehingga pelaksanaannya bisa sesuai dengan susunan kegiatan perencaaan. Siagian (2001: 106) mendefinisikan pengorganisasian sebagai proses pengelompokkan orang-orang, alat-alat, tugas-tugas, tanggung jawab, dan wewenang sedemikian rupa sehingga tercipta suasana organisasi yang dapat digerakkan sebagai suatu kesatuan dalam rangka pencapaian tujuan yang telah ditentukan. Dengan kata lain, pengorganisasian merupakan usaha untuk mengintegrasikan sumber daya manusia dan sumber daya nonmanusia sehingga terbentuk satu kesatuan yang dapat melaksanakan kegiatan yang telah direncanakan, misalkan.

1. Membangkitkan dan menumbuhkan kemauan bela- jar masyarakat dalam rangka terciptanya masyarakat gemar belajar.

2. Memotivasi dan membina warga belajar dalam pelaksanaan asas saling membelajarkan.

3. Melaksanakan Pendidikan Luar Sekolah Pemuda dan Olahraga.

4. Meningkatkan kesejahteraan di segala aspek kehidupan.

5. Memberi pelayanan informasi kepada warga belajar yang memerlukan ketrampilan fungsional.

6. Mengintegrasikan dan menyingkronisasi kegiatan sektoral dalam bidang Pendidikan Luar Sekolah Pemuda dan Olahraga.

7. Menyediakan sarana dan fasilitas belajar.

8. Melakukan urusan tata usaha dan rumah tangga sanggar.

Dalam pengorganisasian dituntut kemampuan penilik dalam melakukan sosialisasi tentang kegiatankegiatan PNF sehingga masyarakat dapat mengetahui maksud dan tujuan pelaksanaan kegiatan tersebut. Berdasarkan jawaban-jawaban informan terkait dengan kegiatan pengorganisasian dan pelaksanaan menunjukkan bahwa selama ini para penilik PNF telah mampu melakukan pengorganisasian terhadap kegiatan PNF, demikian pula dengan tanggung jawab. Dari analisis jawaban informan, dapat diketahui bahwa selama ini penilik telah melaksanakan tugas dengan penuh tanggung jawab. Namun, dalam kegiatan sosialisasi masih harus diakui bahwa penilik belum dapat melaksanakannya secara optimal, padahal sosialisasi diperlukan dalam rangka membangun pengetahuan dan pemahaman masyarakat terhadap program-program yang akan dilaksanakan.

\section{Pengawasan}

Pengawasan dilakukan untuk mengetahui perkembangan kegiatan-kegiatan yang telah diprogramkan. Melalui pengawasan dapat diketahui apakah suatu kegiatan berjalan baik atau tidak. Berdasarkan uraian tersebut dapat dikemukakan bahwa lancar tidaknya kegiatan-kegiatan PNF di masyarakat, sangat tergantung dari lancar tidaknya pengawasan yang dilakukan oleh penilik PNF. Oleh karena itu, seorang penilik PNF harus mampu melakukan pengawasan secara intensif terhadap kegiatan-kegiatan PNF yang telah diprogramkan untuk masyarakat. Selain itu, Penilik PNF harus mampu mendampingi masyarakat dalam pelaksanaan kegiatan-kegiatan PNF. Kegiatan-kegiatan pendampingan terhadap masyarakat dapat diwujudkan melalui pembinaan-pembinaan kepada kelompok-kelompok masyarakat sehingga memahami makna dari program yang dilaksanakan. Selain pembinaan, masyarakat juga memerlukan pembimbingan agar selalu melaksanakan 
kegiatan secara terarah dan terstruktur sesuai dengan susunan perencanaan yang telah dibuat.

Berdasarkan data dari jawaban informan, diketahui bahwa sebagian penilik PNF belum mampu melakukan pengawasan terhadap kegiatan-kegiatan PNF di masyarakat.

Meluasnya sasaran kegiatan-kegiatan PNF hingga ke pelosok-pelosok desa membuat beberapa penilik merasa tidak mampu untuk menjangkau wilayah-wilayah tersebut, sehingga kegiatan cenderung tidak terawasi oleh penilik. Selain mengalami kesulitan dalam hal pengawasan, para penilik tersebut juga mengalami hambatan dalam hal membina dan membimbing masyarakat.

Salah satu kendala penilik dipengaruhi oleh beragamnya karakteristik masyarakat sehingga mengalami kesulitan untuk menguasai khalayak sasaran, seperti yang dilakukan para penilik di empat kecamatan yakni mengembangkan peningkatan strategi serta menggali potensi-potensi yang ada pada masyarakat untuk mengembangkan sektor kerakyatan sehingga terwujud masyarakat yang mandiri.

\section{Evaluasi}

Evaluasi diperlukan untuk mengetahui sejauhmana tingkat keberhasilan suatu program/kegiatan yang telah dilaksanakan. Dari hasil evaluasi, selanjutnya da- pat dianalisis mengenai faktor-faktor yang mempengaruhi kelancaran suatu program, baik faktor yang sifatnya menunjang ataupun yang menghambat pelaksanaan kegiatan dimaksud. Hasil analisis tersebut, dapat dijadikan sebagai referensi untuk perbaikan bagi kegiatan perencanaan dan pelaksanaan program/ kegiatan selanjutnya. Hal ini sebagaimana dijelaskan oleh Mugiadi (dalam Sudjana, 2006: 256) bahwa evaluasi/penilaian adalah upaya pengumpulan informasi menge-nai suatu program, kegiatan atau proyek, di mana informasi tersebut berguna dalam pengambilan keputusan seperti penyempurnaan kegiatan selanjutnya, penghentian suatu kegiatan, atau penyebarluasan gaga-san yang mendasari suatu kegiatan.

Dari informasi yang diperoleh melalui data penelitian diketahui bahwa sejauh ini para penilik PNF selalu melakukan evaluasi terhadap kegiatan-kegiatan PNF. Penilik berpendapat bahwa evaluasi sangat penting untuk mengetahui keberhasilan dari programprogram PNF yang dilaksanakan. Dengan demikian, dapat disimpulkan bahwa kemampuan Penilik dalam melakukan evaluasi terhadap pelaksanaan kegiatankegiatan PNF telah optimal. Para penilik juga menyampaikan hasil evaluasi dalam bentuk rekomendasi ke dinas dan UPT sebagai bagian dari peningkatan kinerja penilik, pengelola dan lembaga terkait.

\section{KESIMPULAN}

Analisis kinerja penilik PNF ternyata pada umumnya menunjukkan capaian kualitas belum optimal. Hal ini terlihat pula dari aspek ketercapaian program dan kegiatan kepengawasan pada dimensi operasional tupoksi sebahagian besar pada kategori yang belum sepenuhnya optimal.

Dari hasil penelitian ini, dapat dikemukakan bahwa kinerja penilik PNF terhadap pelaksanaan tupoksinya telah diaktualisasikan sebagaimana diatur dalam Keputusan Menpan No.15/KEP/M.PAN/3/2002, bahwa penilik adalah jabatan fungsional dan jabatan karier yang hanya dapat diduduki oleh PNS. Penilik mempunyai tugas, tanggung jawab, wewenang, dan hak untuk melakukan pemantauan, penilaian dan bimbingan terhadap penyelenggaraan pendidikan luar sekolah.

Berdasarkan temuan penelitian dan simpulan yang telah dikemukakan, maka disarankan antara lain.

Pertama, untuk meningkatkan kualitas kinerja kepenilikan maka para penilik PNF perlu memahami dan mengaplikasikan tupoksinya sebagaimana telah diatur dalam Keputusan Menpan No.15/KEP/M.PAN/
3/2002, sehingga dapat dicapai optimalisasi kinerja aksi dan kinerja hasil PNF.

Kedua, tuntutan kualifikasi dan kompetensi dalam pelaksanaan tugas dan profesi pada dasarnya merupakan inovasi terhadap pembaharuan dan peningkatan kualitas kinerja pelaksanaan tupoksi termasuk kualitas kegiatan kepengawasan PNF. Oleh karena itu, para penilik PNF hendaknya memiliki kualifikasi akademik yang ditetapkan dalam hal berkualifikasi pendidikan Sarjana (Strata Satu) dan/atau Diploma IV, sesuai Peraturan Pemerintah Nomor 19 tahun 2005 Tentanh Standar Nasional Pendidikan (SNP).

Ketiga, untuk meningkatkan kompetensi pelaksanaan tugas fungsional kepenilikan PNF, perlunya pelatihan terhadap penilik-penilik PNF guna meningkatkan kemampuan mereka yang pada gilirannya dapat mengimplementasikan tugas pokok dan fungsinya secara optimal.

Keempat, perlunya pemanfaatan wadah IPI sebagai forum komunikasi antarpenilik dalam rangka peningkatan kualitas dan kinerja penilik dalam pelaksanaan tupoksinya. Wadah IPI dapat menjadi forum pengem- 
bangan kreativitas, inovasi, ide dan gagasan para penilik dalam mengembangkan dan mengimplementasikan program dan kegiatan PNF yang bermakna dan sangat dibutuhkan oleh masyarakat.

\section{DAFTAR PUSTAKA}

Alfonso, R.J., Firth, G.R., \& Neville, R. (1981). Instructional supervision, a behavior system. Boston: Allyn and bacon, Inc.

Bacal, R. (1989). Performance management. Terjemahan. Jakarta: Gramedia Pustaka Utama.

Depdiknas, Dirjen Peningkatan Mutu Pendidik dan Tenaga Kependidikan, Direktorat PTKPNF. (2007). Perubahan keputusan MENPAN nomor 15/KEP.M/PAN/3/2002 tentang jabatan fungsional penilik dan angka kreditnya.

Direktorat PTKPNF. (2008). Profil direktorat PTKPNF. Diakses pada tanggal 30 Januari 2011 dari http:/ //jugaguru.com

Drucker, P. F. (1977). An introductory view of management. New York: Harper's College Press.

Husain, R. (2010). Kinerja penilik pendidikan nonformal dalam pelaksanaan tupoksinya di kabupaten Gorontalo. Makalah.

Ikatan Penilik Indonesia (IPI). (2009). Buku penilik pendidikan nonformal dan informal. Gorontalo: IPI Provinsi Gorontalo.

Keputusan Menteri Negara Pendayagunaan Aparatur Negera Nomor 118/1996

Masaong, A. K. (2011). Supervisi pendidikan. Bandung: MQS Publishing.

Media Informasi Penilik Indonesia. (2007). Mari kita wujudkan penilik sebagai quality assurance.
Diakses pada tanggal 20 Februari 2011 dari http:/ /penilikpls.bolgspot.com.

Mello, J. A. (2002). Strategic human resource management. Cincinnati. Ohio: South-Western College Publishing.

Moleong, J. L. (2001). Metode penelitian kualitatif. Jakarta: Rosda Karya.

Nawawi, H. H. (2001). Manajemen sumber daya manusia. Yogyakarta: Gajah Mada University Press.

Peraturan Pemerintah Nomor 19 tahun 2005 tentang Standar Nasional Pendidikan (SNP).

Robbin. (2005). A philosopher looks at science. New Jersey: Yale Univ.Press.

Rohani, H. M. A. (1991). Administrasi pendidikan. Jakarta: Rineka Cipta.

Siagian, S. P. (2003). Filsafat administrasi. (Edisi Revisi). Jakarta: PT. Bumi Aksara.

Siahaan, A. (2006). Manajemen pengawas pendidikan. Ciputat: Quantum Teaching.

Sinaulan, J. H. (2007). Studi tentang perilaku organisasi pada sekolah menengah atas negeri provinsi DKI Jakarta. Bandung: Disertasi Universitas Pendidikan Indonesia. Tidak Diterbitkan.

Sudjana. (2006). Pendidikan nonformal. Bandung: Falah Production.

Tuloli, H. J. (2002). Metode penelitian kualitatif dan aplikasinya. Gorontalo. 